Maurer School of Law: Indiana University

Digital Repository @ Maurer Law

1977

\title{
Charge Reduction: An Intermediary Stage in the Process of Labelling Criminal Defendants
}

\author{
Ilene Nagel Bernstein \\ Indiana University School of Law - Bloomington \\ Edward Kick \\ Indiana University - Bloomington \\ Jan T. Leung \\ Indiana University - Bloomington \\ Barbara Schulz \\ Indiana University - Bloomington
}

Follow this and additional works at: https://www.repository.law.indiana.edu/facpub

Part of the Criminal Law Commons, and the Criminology and Criminal Justice Commons

\section{Recommended Citation}

Bernstein, Ilene Nagel; Kick, Edward; Leung, Jan T.; and Schulz, Barbara, "Charge Reduction: An Intermediary Stage in the Process of Labelling Criminal Defendants" (1977). Articles by Maurer Faculty. 2071.

https://www.repository.law.indiana.edu/facpub/2071

This Article is brought to you for free and open access by the Faculty Scholarship at Digital Repository @ Maurer Law. It has been accepted for inclusion in Articles by Maurer Faculty by an authorized administrator of Digital Repository @ Maurer Law. For more information, please contactrvaughan@indiana.edu. 


\title{
Charge Reduction: An Intermediary Stage in the Process of Labelling Criminal Defendants*
}

\author{
I L E N E A G E B ER NSTEIN, Indiana University \\ E D W A R D KI C K, Indiana University \\ J A N T. L E U N G, Indiana University \\ B A R B A R A S H U L Z, Indiana University
}

\begin{abstract}
The interactionist perspective emphasizes the imperfect correspondence between alleged deviance and societal reactions. Moreover, it is asserted that values of reactors, statuses of the alleged deviant, and bureaucratic constraints of deviance processing organizations help explain some of that imperfection. Focusing on one intermediary deviance processing stage, i.e., plea bargaining, we explore the degree to which our data are consonant with interactionist assumptions. For a sample of 1,435 male and female criminal defendants, we find the favorability of the charge reduction outcome is partly explained by values of reactors, statuses of the defendant, and bureaucratic constraints of the court. Thus, our data are supportive of the general thrust of interactionist works. However, the relative size of each of these effects suggests that reformulations of that perspective should attend to the finding that ascribed statuses play far less of a determinative role, and organizational goals seem to play a more determinative role, suggesting that greater attention be paid to organizational variables.
\end{abstract}

For at least two decades, sociologists have attended to the propositions of the naturalistic, interactionist, or labelling approach to deviance. Recently this approach has come under serious attack (Gibbs, b; Gove; Hirschi; Tittle) because empirical work has failed to confirm its explanatory power. But some have argued that the methodological limitations of extant research also make it impossible to reject the perspective. Although there is still

\footnotetext{
* Partial support for this research was provided by a 'Daniel and Florence Guggenheim Research Fellowship to the senior author during her year of residence at Yale Law School. Special thanks are extended to Martin Barr, Lucy Friedman, and Charles Kuhlman for providing the quantitative data for these analyses, and to John Cardascia for comments on an earlier draft.
} 
room for conceptual reconciliation, the greatest need is for research that can provide empirical grounds for theoretical elaboration.

The problems in designing and executing such research, however, are not simple. Of prime importance is what appears to be a basic difference of opinion between the proponents and the critics as to whether the approach is a theory or a perspective. According to Becker (c) and Schur (b), labelling theory is not now nor was ever meant to be a theory of deviance; rather, it is a perspective whose purpose is to guide some aspects of deviance research by proposing a set of sensitizing concepts (Goode). Given this, much of the empirical research examined by critics in assessing the strength of the perspective is challenged as inappropriate and misguided. On the other hand, those who have attempted to assess the theory (e.g., Gibbs, a; Gove; Hirschi; Tittle) argue forcefully that a perspective that cannot be operationalized and tested is of limited use for sociology. Our view is that research bearing on hypotheses that "apparently" characterize the perspective should continue in order to provide the means for theoretical specification. Such research will not satisfy proponents or critics, but it can contribute to an empirical base from which a genuine "theory" of societal reactions to deviance might emerge. Thus, exploratory work that seeks to determine which factors affect some particular societal response to deviants is well-suited to the present needs and abilities of deviance research.

The interactionist perspective stresses the imperfect correspondence between deviant acts and the reaction to those acts. Moreover, emphasis is placed on "interaction between those alleged to be engaged in wrongdoing and those making the allegations" (Becker, c: 178). This emphasis expands the study of deviance to include more than the alleged deviants and their alleged deviant acts. By including consideration of those responsible for processing and responding to the alleged deviant, interactionists claim they can better explain societal reactions to deviants (Becker, a; Goode; Kitsuse and Cicourel; Pollner; Schur, a; Scott). Stated more explicitly, factors associated with the values and activities of those responding to a deviant are said to account for some of the variance in the societal reaction.

In addition to an emphasis on the "reactors," the interactionist perspective underscores the importance of studying societal response as a fluid rather than a stagnant process. Hence, it is assumed that labelling decisions made in the early stages of deviance processing will have consequences for decisions made in the latter stages (Becker, c; Lofland). Individuals are said to enter each deviance processing stage with a variety of statuses, some of which are ascribed (e.g., sex), some of which are achieved (e.g., years of schooling completed), and some of which are themselves the results of prior interactions between the alleged deviant and some deviance processing agents. To the extent that these statuses significantly affect the subsequent placement of individuals into deviance categories for fur- 
ther processing, any research seeking to model societal responses must take this into account. Accordingly, the interactionist perspective suggests (1) that greater attention be paid to the interim stages of deviance processing (e.g., plea bargaining in the processing of criminal defendants), and (2) that attempts to explain variation in the societal response estimate the determinative role of statuses resulting from prior deviance processing.

A careful reading of interactionist literature (e.g., Becker, a; Erikson; Goode; Kitsuse and Cicourel; Schur, a; Scott) suggests that the following factors additionally mediate the relationship between deviant acts and the societal response. First, the power of the deviant relative to the deviance controlling agents is asserted to be a basis for differentiating the societal response (Becker, a; Rubington and Weinberg; Schur, a). The assumption is that marginal members of society have less power to resist the imposition of deviant labels. Accordingly, one might contend that a core assertion of the interactionist perspective is: individuals with socially disadvantaged statuses (e.g., blacks, youth) will be less likely to receive the more favorable societal response. ${ }^{1}$ Second, the organizational imperatives of deviance controlling agencies are asserted to influence societal responses. Blumberg, Schur (a), and Becker (c) suggest that to the extent that the behavior of an individual conflicts with the organizational goals of the deviance controlling agency (e.g., resisting arrest) one can expect the societal response to such persons to be less favorable. Last, a host of ancillary and contingency factors interpretable as examples of factors Schur (a) had in mind when he discussed stereotyping, retrospective interpretation, and negotiation are put forth to account for how the quality of deviantness is differentially imputed to acts and to people. To illustrate: if a defendant is prosecuted for robbing a seventy-year old woman, s/he may be more negatively responded to because of stereotypic attributions (e.g., sadism) made about persons who victimize the elderly. Retrospective interpretation would characterize the practice of assuming culpability for criminal deviance partly on the basis of noting a defendant's prior conviction for the same type of offense. An example of negotiator ability would be a criminal defendant's refusal to accept a plea offer when s/he knows from prior experience that a better offer may be forthcoming.

In the area of criminal justice, an area believed by many (e.g., Tittle) to be strategic for examining societal response decisions, there has been a dearth of empirical research that treats the plea bargain as a societal response to be explained. Since plea bargaining is the major mode of case disposition in the American Criminal Justice system, with approximately 90 percent of all criminal dispositions resulting from plea bargains (Newman, b; U.S. Department of Justice), examination of this interim stage is critical. This is not to demean the valuable work of Sudnow, Newman (b), Blumberg, Schur (a), and Rosett and Cressey, all of which provide important qualitative analyses of non-trial adjudicated dispositions. Rather, it is 
to underscore the need for complementary quantitative research that provides estimates of (1) the amount of variance in the favorability of the plea bargain accounted for by the alleged deviant act, and (2) the amount of additional variance accounted for by prior deviance processing decisions, by the deviants' social attributes, by the values and expectations of the deviance processing agents, and by the organizational imperatives of the deviance processing agency. To the extent that the "assumptions" or "assertions" articulated in the interactionist perspective generally are applicable to criminal justice, these latter four variables should explain outcomes of the plea bargaining process, net of the characteristics of the alleged criminal act.

\section{Research Question}

Although the plea bargaining process may involve several types of negotiations (such as for lesser sentences, for conviction on fewer charges, or for concurrent sentences), the major works on plea bargaining suggest the principle plea bargaining process seems to be that of charge reduction (Blumberg; Cressey; Miller; Newman, a, b; Rosett and Cressey; Sudnow; Vetri; Wells).

Charge reduction is especially important if it culminates in conviction. The conviction label is important because it establishes the severity of the offense for which a defendant is sanctioned (thereby restricting the sentencing options), and the crime category into which the defendant may be forever typed (e.g., robbery, assault). Additionally, subsequent decisions (e.g., sentence, parole) may be affected by this label as well. And, to the extent that the defendant ever re-enters the criminal justice system, this label may additionally serve as one major determinant of future deviance processing decisions.

Consequently, the general research question guiding this exploratory effort is: To what degree is the response to deviants, as measured by the favorability of a defendant's charge reduction, accounted for by factors other than the alleged deviant act? Moreover, we seek to examine the degree to which those factors emphasized by interactionists as important determinants of societal responses account for some of the explained variance in the favorability of charge reduction outcomes.

\section{Dependent Variables}

The favorability of the charge reduction process is measured here by two indices. The first $\left(Y_{1}\right)$ is a measure of the magnitude of the reduction relative to the absolute reduction possible. The second $\left(Y_{2}\right)$ is simply the 
severity of the charge for which the defendant was convicted. We assume that the greater the charge reduction, the more favorable the societal response; and, the less severe the final conviction charge, the more favorable the societal response.

The $Y_{1}$ index was constructed by taking the change in severity of charge from prosecution to conviction charge as the numerator, and the change in severity of charge from prosecution charge to the lowest severity charge possible at conviction as the denominator. (Severity is coded in increasing severity from 1-8 where 1 is a violation or unclassified misdemeanor, 2 is a B misdemeanor, 3 is an A misdemeanor, 4 is an E felony, 5 is a D felony, 6 is a $C$ felony, 7 is a $B$ felony, and 8 is an A felony. The letter codes and felony/misdemeanor/violation categories are in accordance with the specifications of the New York Penal law code.) For example, if a defendant's most serious prosecution charge (the charge at his/her first court presentation) is a $C$ felony (e.g., second degree burglary) the severity code for that charge is a 6 . If that defendant's most serious charge for which s/he was convicted is an A misdemeanor (e.g., possession of burglar's tools) the severity code for that conviction charge is a 3 . The difference of $3(6-3)$ between the prosecution charge and the conviction charge is the amount of reduction, i.e., the numerator. The denominator is calculated by taking the difference between the severity code of the prosecution charge (using the same example, 6) and the severity code of the lowest charge for which the defendant could have been convicted, i.e., a violation, which carries a severity code of 1 . The difference here $(6-1)$ is 5 . Thus, for this sample defendant, the amount of reduction relative to the amount possible would be $3 / 5$ or $.60 . Y_{1}$ ranges from 0 for defendants whose conviction charge was identical to the charge for which they were prosecuted, to 1 for defendants whose reduction was equivalent to the total reduction possible, in other words, to a violation.

$Y_{2}$ is the severity code of the most serious charge for which the defendant is convicted. An A misdemeanor is scored 3, a B misdemeanor scored 2, and a violation scored 1 . Since it is the severity of this charge that is likely to have a major effect on subsequent deviance processing decisions (see, for example, Hagan b; Newman, b; Schwartz and Skolnick) we analyze variation in this outcome separately from the $Y_{1}$ measure discussed above.

\section{Independent Variables}

Much of the prior research on the response to deviants (e.g., Green; Hagan, a; Nagel) classifies independent variables into two categories, i.e., legal variables, e.g., type offense, prior criminal record, severity of charge, and extra-legal variables, e.g., age, race, sex, and economic status. We find 
this distinction inappropriate for three reasons. First, there is considerable variation from one jurisdiction to another in the procedural law that stipulates what factors are legal versus those that are extralegal in criminal justice decisions. Second, what is specified in a statute as legal for one stage of criminal justice processing may not be legal for another stage, e.g., community ties (flight risk) is generally a legal consideration for pre-trial release status decisions, but not for plea bargaining or sentencing decisions. Third, some variables ordinarily placed in the "legal" category (e.g., prior record of convictions) may themselves have resulted from some combination of consideration of legal and extra-legal variables in some prior processing. Thus, the legal/extra-legal distinction becomes confused by the prior meshing of legal/extra-legal combinations into one category. These concerns, coupled with the general lack of specificity by interactionists about which exact variables are valid indicators of social disadvantaged status, reactors' values, stereotyping, organizational imperatives, and the like leads us to include in our research those variables that we believe would likely affect the charge reduction process. We base our decision as to which variables to include on our reading of the interactionist works, our observations of the court processes, and findings of prior research. A list of variables examined appears in Table 1.

Table 1. VARIABLES: SCALING, NOTATION, AND FREQUENCIES

\begin{tabular}{|c|c|c|c|c|}
\hline \multirow[b]{2}{*}{ Notation } & \multirow[b]{2}{*}{ Variable } & \multirow[b]{2}{*}{ Scale } & \multicolumn{2}{|c|}{ Frequencies } \\
\hline & & & $\begin{array}{l}\text { Disposed of } \\
\text { at First } \\
\text { Presentation } \\
(N=458)\end{array}$ & $\begin{array}{l}\text { Not Disposed } \\
\text { of at First } \\
\text { Presentation } \\
(N=977)\end{array}$ \\
\hline \multirow[t]{3}{*}{$Y_{1}$} & $\begin{array}{l}\text { Magnitude of charge } \\
\text { reduction between first } \\
\text { presentation and disposi- } \\
\text { tion as a proportion of total }\end{array}$ & $\begin{array}{l}0 \text { No reduction } \\
.01-.99 \text { Reduction } \\
\text { as proportion of } \\
\text { total possible }\end{array}$ & $\begin{array}{ll}21 \% & (95) \\
54 \% & (247)\end{array}$ & $\begin{aligned} 9 \% & (90) \\
72 \% & (699)\end{aligned}$ \\
\hline & possible reduction & $\begin{array}{l}1 \text { Reduced to } \\
\text { violation }\end{array}$ & $25 \%(116)$ & $19 \%(190)$ \\
\hline & & & $\bar{x}=.50$ & $\bar{x}=.50$ \\
\hline \multirow[t]{3}{*}{$Y_{2}$} & $\begin{array}{l}\text { Severity of most severe } \\
\text { conviction charge }\end{array}$ & $\begin{array}{l}1 \text { Violation or un- } \\
\text { classified mis- } \\
\text { demeanor }\end{array}$ & $25 \%(117)$ & $20 \%(193)$ \\
\hline & & 2 B misdemeanor & $30 \%(135)$ & $22 \%(214)$ \\
\hline & & $3 \mathrm{~A}$ misdemeanor & $\begin{array}{c}45 \%(206) \\
\bar{X}=2.17\end{array}$ & $\begin{array}{c}58 \%(570) \\
\bar{X}=2.43\end{array}$ \\
\hline
\end{tabular}


Table 1, Continued.

\begin{tabular}{|c|c|c|c|c|}
\hline \multirow[b]{2}{*}{ Notation } & \multirow[b]{2}{*}{ Variable } & \multirow[b]{2}{*}{ Scale } & \multicolumn{2}{|c|}{ Frequencies } \\
\hline & & & $\begin{array}{l}\text { Disposed of } \\
\text { at First } \\
\text { Presentation } \\
(N=458)\end{array}$ & $\begin{array}{l}\text { Not Disposed } \\
\text { of at First } \\
\text { Presentation } \\
(N=977)\end{array}$ \\
\hline$x_{1}$ & $\begin{array}{l}\text { Severity of most severe } \\
\text { first presentation charge }\end{array}$ & $\begin{array}{l}2 \text { B misdemeanor } \\
3 \text { A misdemeanor } \\
4 \text { E felony } \\
5 \text { D felony } \\
6 \text { C felony } \\
7 \text { B felony }\end{array}$ & $\begin{aligned} 2 \% & (11) \\
37 \% & (169) \\
24 \% & (112) \\
32 \% & (147) \\
4 \% & (18) \\
0 \% & (1) \\
\bar{X} & =4.95\end{aligned}$ & $\begin{aligned} 1 \% & (11) \\
18 \% & (171) \\
20 \% & (198) \\
44 \% & (434) \\
12 \% & (112) \\
5 \% & (51) \\
\bar{X}= & 5.63\end{aligned}$ \\
\hline$x_{2}$ & $\begin{array}{l}\text { Most severe first presen- } \\
\text { tation charge is a felony }\end{array}$ & $\begin{aligned}-1 & \text { No } \\
1 & \text { Yes }\end{aligned}$ & $\begin{array}{l}39 \%(180) \\
61 \%(278)\end{array}$ & $\begin{array}{ll}19 \% & (182) \\
81 \% & (795)\end{array}$ \\
\hline$x_{3}$ & $\begin{array}{l}\text { Type of crime at first } \\
\text { presentation }\end{array}$ & & & \\
\hline & Burglary or related & $\begin{aligned}-1 & \text { No (larceny) } \\
0 & \text { No (assault, } \\
& \text { robbery) } \\
1 & \text { Yes (burglary) }\end{aligned}$ & $\begin{array}{ll}46 \% & (211) \\
19 \% & (88) \\
35 \% & (159)\end{array}$ & $\begin{array}{ll}37 \% & (358) \\
34 \% & (345) \\
37 \% & (358)\end{array}$ \\
\hline & Assault & $\begin{aligned} &-1 \text { No (larceny) } \\
& 0 \text { No (burglary, } \\
& \text { robbery) } \\
& 1 \text { Yes (assault) }\end{aligned}$ & $\begin{array}{ll}46 \% & (211) \\
38 \% & (173) \\
16 \% & (74)\end{array}$ & $\begin{array}{ll}37 \% & (358) \\
42 \% & (412) \\
& \\
21 \% & (207)\end{array}$ \\
\hline & Robbery & $\begin{aligned} &-1 \text { No (larceny) } \\
& 0 \text { No (assault, } \\
& \text { burglary) } \\
& 1 \text { Yes (robbery) } \\
& \text { (excluded category) }\end{aligned}$ & $\begin{aligned} 46 \% & (211) \\
51 \% & (233) \\
& \\
3 \% & (14) \\
46 \% & (211)\end{aligned}$ & $\begin{array}{ll}37 \% & (358) \\
50 \% & (491) \\
& \\
13 \% & (128) \\
37 \% & (358)\end{array}$ \\
\hline$x_{4}$ & $\begin{array}{l}\text { Total number of first pre- } \\
\text { sentation charges }\end{array}$ & $\begin{array}{l}\text { Interval scale } \\
(1 \text { to } 5)\end{array}$ & $\bar{X}=1.1$ & $\bar{x}=1.1$ \\
\hline$x_{5}$ & $\begin{array}{l}\text { First presentation charges } \\
\text { include possession of } \\
\text { weapon charge }\end{array}$ & $\begin{aligned}-1 & \text { No } \\
1 & \text { Yes }\end{aligned}$ & $\begin{aligned} 97 \% & (443) \\
3 \% & (15)\end{aligned}$ & $\begin{aligned} 95 \% & (928) \\
5 \% & (49)\end{aligned}$ \\
\hline$x_{6}$ & $\begin{array}{l}\text { First presentation charges } \\
\text { include resist arrest } \\
\text { charges }\end{array}$ & $\begin{aligned}-1 & \text { No } \\
1 & \text { Yes }\end{aligned}$ & $\begin{aligned} 95 \% & (435) \\
5 \% & (23)\end{aligned}$ & $\begin{aligned} 92 \% & (899) \\
8 \% & (78)\end{aligned}$ \\
\hline
\end{tabular}


Charge Reduction / 369

Table 1, Continued.

\begin{tabular}{|c|c|c|c|c|}
\hline \multirow[b]{2}{*}{ Notation } & \multirow[b]{2}{*}{ Variable } & \multirow[b]{2}{*}{ Scale } & \multicolumn{2}{|c|}{ Frequencies } \\
\hline & & & $\begin{array}{l}\text { Disposed of } \\
\text { at First } \\
\text { Presentation } \\
(N=458)\end{array}$ & $\begin{array}{l}\text { Not Disposed } \\
\text { of at First } \\
\text { Presentation } \\
(N=977)\end{array}$ \\
\hline \multirow[t]{3}{*}{$x_{7}$} & Race/Ethnicity & & & \\
\hline & Spanish surname & $\begin{aligned}-1 & \text { No (White) } \\
0 & \text { No (Black) } \\
1 & \text { Yes (Spanish) }\end{aligned}$ & $\begin{array}{ll}13 \% & (59) \\
44 \% & (193) \\
43 \% & (191)\end{array}$ & $\begin{array}{cl}9 \% & (84) \\
48 \% & (452) \\
44 \% & (414)\end{array}$ \\
\hline & Black & $\begin{aligned} &-1 \text { No (White) } \\
& 0 \text { No (Spanish) } \\
& 1 \text { Yes (Black) } \\
& \text { (excluded category) }\end{aligned}$ & $\begin{array}{ll}13 \% & (59) \\
43 \% & (191) \\
44 \% & (193) \\
13 \% & (59)\end{array}$ & $\begin{aligned} 9 \% & (84) \\
44 \% & (414) \\
48 \% & (452) \\
9 \% & (84)\end{aligned}$ \\
\hline$x_{B}$ & Sex & $\begin{array}{l}-1 \text { Female } \\
1 \text { Male }\end{array}$ & $\begin{array}{ll}12 \% & (56) \\
88 \% & (392)\end{array}$ & $\begin{array}{l}14 \%(139) \\
86 \%(818)\end{array}$ \\
\hline$x_{8}$ & Age & $\begin{array}{l}\text { Interval scale } \\
(15-75)\end{array}$ & $\bar{x}=26.7$ & $\bar{x}=26.0$ \\
\hline$x_{10}$ & Years of school completed & $\begin{array}{l}\text { Interval scale } \\
(0 \text { to } 20)\end{array}$ & $\bar{x}=9.8$ & $\bar{x}=10.2$ \\
\hline \multirow[t]{3}{*}{$x_{11}$} & Criminal Record & & & \\
\hline & None & $\begin{aligned}-1 & \text { No (conviction) } \\
0 & \text { No (arrests) } \\
1 & \text { Yes (none) }\end{aligned}$ & $\begin{array}{ll}38 \% & (111) \\
21 \% & (62) \\
41 \% & (118)\end{array}$ & $\begin{array}{ll}33 \% & (224) \\
22 \% & (148) \\
46 \% & (312)\end{array}$ \\
\hline & $\begin{array}{l}\text { Arrests, no convictions } \\
\text { Convictions }\end{array}$ & $\begin{aligned} &-1 \text { No (conviction) } \\
& 0 \text { No (none) } \\
& 1 \text { Yes (arrests) } \\
& \text { (excluded category) }\end{aligned}$ & $\begin{array}{ll}38 \% & (111) \\
41 \% & (118) \\
21 \% & (62) \\
38 \% & (111)\end{array}$ & $\begin{array}{ll}33 \% & (224) \\
46 \% & (312) \\
22 \% & (148) \\
33 \% & (224)\end{array}$ \\
\hline$x_{12}$ & $\begin{array}{l}\text { Has another case } \\
\text { pending in court }\end{array}$ & $\begin{aligned}-1 & \text { No } \\
1 & \text { Yes }\end{aligned}$ & $\begin{array}{l}72 \%(315) \\
28 \%(120)\end{array}$ & $\begin{array}{ll}73 \% & (685) \\
27 \% & (252)\end{array}$ \\
\hline$x_{13}$ & $\begin{array}{l}\text { Number of court } \\
\text { appearances }\end{array}$ & $\begin{array}{l}\text { Interval scale } \\
(1 \text { to 13) }\end{array}$ & constant & $\bar{x}=3.7$ \\
\hline$x_{14}$ & $\begin{array}{l}\text { Court congestion index } \\
\text { (for persons disposed of } \\
\text { at first presentation) }\end{array}$ & Interval scale & a & -0 \\
\hline$x_{15}$ & $\begin{array}{l}\text { Pretrial release status } \\
\text { of persons not disposed } \\
\text { of at first presentation }\end{array}$ & $\begin{array}{l}-1 \text { released } \\
1 \text { detained }\end{array}$ & $-^{c}$ & $\begin{array}{ll}39 \% & (379) \\
61 \% & (592)\end{array}$ \\
\hline
\end{tabular}

-Score represents standard deviation units from mean daily court congestion for period included.

Data not available.

Not applicable. 
Age, race, education, and sex of the defendant are included because they are thought to imply something about minority status and the relative power of defendants. It is suggested in the interactionist literature that older, white, more educated, and male defendants are more likely to receive the more favorable societal responses (Knowles and Prewitt; Quinney; Reasons). ${ }^{2}$ Assuming the interactionist thesis is trans-situational, we expect these same status considerations to affect the favorability of the charge reduction process.

The defendant's prior criminal record is included because Becker (b) and Emerson have posited that prior record is a label used in formal and informal deviance processing. More specifically, Schur's (a) assertion that societal reactors use "retrospective interpretation" to determine their response, suggests that a defendant's prior criminal record may be used as a means to assess a defendant's character. If a defendant has a prior conviction, assumptions about his/her culpability in the present case and the appropriate responses to that case may be influenced by his/her alleged past. Interestingly, Newman (b) argues that defendants having prior experience with the criminal justice system fare better in negotiating charge reduction because their prior experience makes them better "bargainers." But this is also consonant with Schur's (a) assertion that a defendant's negotiator abilities may influence the societal response. The fact that findings in either direction are interpretable as supportive of Schur's discussion is illustrative of the difficulty in "testing" the explanatory power of the interactionist perspective.

A defendant's release status pending final disposition of his/her case is similarly a label brought forth from a prior stage of deviance processing. Since the decision to release or detain a defendant is purportedly based on considerations of flight risk (irresponsibility), danger, and/or economic resources, this label too can be used to assess the defendant's character and to affect the response to his/her alleged offense. Ares et al., Landes (a), Roballo et al., and Wald and Freed argue that detained defendants carry an additional "negative label" through the criminal justice process. Moreover, Bernstein et al. find that the label "detainee" has a large independent negative effect on sanctioning decisions.

Court congestion, a measure of the workload of the court on a particular day, is examined because of its presumed relation to the organizational imperative to process cases rapidly. Blumberg argues that organizational constraints limit the number of persons that can be processed, as well as the amount of time used to process them. Therefore, it may be that court congestion will cause court members to attempt to speed up the plea bargain process by offering better charge reductions than would be offered under less-congested circumstances. Similarly, the fewer the number of scheduled appearances a defendant has, the greater the expectation that s/he will be more favorably responded to since every appearance impedes 
the court's organizational goal to clear the docket (Blumberg; Rosett and Cressey). Last, defendants whose charges include a "resisting arrest" charge are expected to fare less well in the charge reduction process because an organizational goal is the maintenance of good relationships between court personnel and the police. To the extent that "resisting arrest" is an affront to the police, the court is expected to respond less favorably to those so charged (Chambliss and Seidman).

The type of offense for which the defendant is prosecuted is examined because prior research has suggested that the type as well as the severity of the offense affects court decisions. Turk, and Bernstein et al. find that offenses of the same severity are differentially responded to according to attitudes held towards certain type crimes. Last, a variety of variables representing other characteristics of the alleged offense, e.g., severity of the most serious charge for which the defendant was prosecuted, number of charges for which the defendant was prosecuted, and whether the charges included a possession of a dangerous weapon are examined to assess their independent relationships to the favorability of the charge reduction outcomes. The exact means by which each independent variable is coded is noted in Table 1.

\section{Analysis}

Multiple regression procedures (see Cohen; Kerlinger and Pedhazur) are used to analyze these data. Nominal variables are effect coded in accordance with the arguments of Kerlinger and Pedhazur (172-85) that effect coding (comparing each category to the mean of all the other categories rather than to an arbitrarily defined left out category) is appropriate in exploratory research. To illustrate, larceny is compared to the mean of robbery, assault and burglary rather than larceny to some left out category selected from among robbery, assault and burglary. See $X_{3}$ in Table 1 for further detail.

The analyses are done separately for two groups of defendants; those defendants whose cases were finally disposed of at their first court presentation (at arraignment, $n=458$ ), and those defendants whose court cases were finally disposed of sometime after their first court presentation $(n=977)$. These two groups are analyzed separately because they differ so greatly in the time they are involved in the process. Since the entire court processing from arrest to disposition for the "early disposed" takes less than 48 hours, it is likely that different factors affect the charge reduction process than for those who are there for weeks or months. For example, we noted that prior research shows that the pre-trial release status of the accused affects subsequent processing decisions. However, defendants whose cases are disposed of at first presentation do not have such a status. 
Similarly, there is no variation among those defendants on the number of pre-trial appearances. Finally, Bernstein et al. find the bases for adjudication and sanctioning decisions to differ for those early versus later disposed. Since the difference manifests itself at these other two deviance processing stages, we thought it critical to explore that possibility for this interim stage as well.

The independent variables included in the final regression equations used to produce Tables 3 and 4 were selected for inclusion if their net effect was statistically significant at .05 . Accordingly, if a variable appears in Table 2 and not in Tables 3 and 4 , the net effect of that independent variable was not statistically significant. However, the severity of the first presentation charge is included in every equation because we deemed it a theoretically important control variable.

\section{Sample}

Data are analyzed for a sample of 1,435 male and female defendants arraigned and convicted in a criminal (misdemeanor) court between December 1974 and February 1975, in a major metropolitan city in New York State. Although a misdemeanor court, this court processes upwards of twothirds of all criminal cases including cases prosecuted as felonies. The 1,435 cases represent all persons whose most severe charge at first court presentation was a second or third degree burglary or related offenses, a first, second, or third degree assault, a second or third degree grand larceny, petit larceny, or a first, second or third degree robbery. We selected only those defendants prosecuted for charges in one of these four crime categories (burglary, assault, larceny, robbery) so that we could limit the variability in crime categories and assess how variation among those categories affected our dependent variables. For each of the 1,435 cases, biographical information on the defendant was obtained through personal interviews conducted with the defendant immediately after his/her arrest and before his/her court presentation. Criminal record data were coded from state criminal records, and information relevant to the charged offense was recorded from criminal court records. Information relevant to the defendant's experiences as his/her case was processed through the court was coded from court records as well. Finally, in addition to the quantitative data collected, supplementary qualitative data were collected from court observations and interviews with judges, prosecutors, defense attorneys, and other court personnel. 
Table 2. ZERO-ORDER CORRELATION COEFFICIENTS FOR ALL INDEPENDENT VARIABLES WITH EACH DEPENDENT VARIABLE FOR CASES DISPOSED OF AT FIRST PRESENTATION $(N=301)$ AND CASES NOT DISPOSED OF AT FIRST PRESENTATION $(N=675)^{*}$

\begin{tabular}{|c|c|c|c|c|c|}
\hline \multirow{2}{*}{\multicolumn{2}{|c|}{ Independent Variables }} & \multicolumn{2}{|c|}{$\begin{array}{c}\text { Disposed of at } \\
\text { First Presentation }\end{array}$} & \multicolumn{2}{|c|}{$\begin{array}{l}\text { Not Disposed of a } \\
\text { First Presentation }\end{array}$} \\
\hline & & $Y_{1}$ & $Y_{2}$ & $Y_{1}$ & $Y_{2}$ \\
\hline$x_{1}$ & $\begin{array}{l}\text { Severity of first } \\
\text { presentation charge }\end{array}$ & .08 & - & .21 & - \\
\hline$x_{2}$ & $\begin{array}{l}\text { First presentation } \\
\text { charge is felony }\end{array}$ & - & .32 & - & .19 \\
\hline$x_{3}$ & $\begin{array}{l}\text { Type of crime } \\
\text { Burglary } \\
\text { Assault } \\
\text { Robbery }\end{array}$ & $\begin{array}{r}.03 \\
-.01 \\
.00\end{array}$ & $\begin{array}{l}.08 \\
.12 \\
.13\end{array}$ & $\begin{array}{r}-.05 \\
-.04 \\
.04\end{array}$ & $\begin{array}{l}.18 \\
.23 \\
.21\end{array}$ \\
\hline$x_{4}$ & Number charges & - & -.03 & -.01 & .04 \\
\hline$x_{5}$ & Weapon charge & .10 & -.07 & .07 & .01 \\
\hline$x_{6}$ & Resist arrest charge & -.16 & .18 & -.22 & .23 \\
\hline$x_{7}$ & $\begin{array}{l}\text { Race } \\
\text { Spanish surname } \\
\text { Black }\end{array}$ & $\begin{array}{l}.00 \\
.07\end{array}$ & $\begin{array}{r}.01 \\
-.05\end{array}$ & $\begin{array}{r}-.01 \\
.10\end{array}$ & $\begin{array}{r}.01 \\
-.12\end{array}$ \\
\hline$x_{8}$ & Sex & -.12 & .18 & -.15 & .08 \\
\hline$x_{9}$ & Age & -.19 & .21 & -.02 & .04 \\
\hline$x_{10}$ & Education & .06 & -.10 & .02 & -.04 \\
\hline$x_{11}$ & $\begin{array}{l}\text { Criminal record } \\
\text { None } \\
\text { Arrest(s) only }\end{array}$ & $\begin{array}{r}.07 \\
-.03\end{array}$ & $\begin{array}{r}-.13 \\
.01\end{array}$ & $\begin{array}{r}.10 \\
-.05\end{array}$ & $\begin{array}{r}-.06 \\
.06\end{array}$ \\
\hline$x_{12}$ & $\begin{array}{l}\text { Another case } \\
\text { pending }\end{array}$ & .00 & .07 & -.08 & .05 \\
\hline$x_{13}$ & $\begin{array}{l}\text { Number court } \\
\text { appearances }\end{array}$ & - & - & -.04 & .10 \\
\hline$x_{14}$ & Court congestion & .09 & -.13 & - & - \\
\hline$x_{15}$ & Pretrail detained & - & - & -.04 & -.02 \\
\hline
\end{tabular}

-Correlation coefficients are from regression runs using listwise deletion of cases having missing data. Therefore, the case base has been reduced. 


\section{Results}

Table 3 presents the relationships between our independent variables and $Y_{1}$, the magnitude of the charge reduction. Looking first at the outcome for those defendants whose final disposition occurred at their first court presentation, we note that the largest effects are for the type of crime for which the defendant was prosecuted; defendants prosecuted for assaults are more likely to receive a more favorable reduction than those prosecuted for burglary, robbery, or larceny; and, defendants prosecuted for burglary offenses are least likely to receive a more favorable reduction. Our conversations with court personnel suggest that one reason for the leniency accorded those prosecuted for assaults may be the conception that assaults are acts done in the "heat of the moment." As such, a presumption of spontaneity undercuts a presumption of premeditation. Since premeditation may be indicative of culpability, persons charged with assault and other spontaneous crimes may be more favorably treated by the courts. Additionally, we observed that the overwhelming majority of assault cases processed were alleged to have occurred between friends and relatives. Since the court under observation serves a lower-class catchment area, the victims of these assaults are lower-class persons themselves. Thus, the leniency accorded to assault cases may additionally reflect the courts' adoption of a street-wise definition of assaults as routine for the lowerclass culture, thereby reducing the appropriateness of a more harsh societal response. (For similar findings of less severe responses to defendants whose victims are themselves members of minority groups, see Bernstein et al.; Bensing and Schroeder; Dawson; Garfinkel; Newman, b.)

Defendants prosecuted for felony offenses (rather than misdemeanors) are also likely to receive more favorable reductions. This may be an artifact of our data, because this dependent variable is the actual reduction divided by the reduction possible, and felony cases have a greater reduction possible. However, it may also be interpreted to reflect deference to the organizational goal of the court to keep defendants in criminal (misdemeanor) court. Recall, criminal court can only dispose of cases in which the conviction charge is a misdemeanor or violation; to convict a defendant of a felony, the case must be waived to Supreme Court. Supreme Court, however, is very overloaded with backlog cases. As such, there is tremendous pressure to resolve as many cases as possible within criminal court. This explains why we often have heard prosecutors say "... in an attempt to keep this case in criminal court, the people are prepared to accept a plea of guilty to a misdemeanor. ... .

Turning to our indicators of social power, we find the age of defendants affects the favorability of charge reductions, with older defendants being the more likely recipients of the more favorable reduction. While sex and race have no significant direct effects, the finding that older defen- 
dants fare better is consistent with the interactionist assertion. Together, however, these variables do not play the major determinative role in this response decision.

Finally, we find that defendants for whom this is a first arrest do least well on this outcome, and defendants having prior arrests but no convictions do best on this outcome. This challenges the argument (Becker, b) that negative labels picked up in prior deviance processing (e.g., prior criminal record) have negative effects on subsequent deviance processing decisions. Newman's (a) contention that experienced defendants may fare better in plea negotiations by virtue of their knowledge of the workings of that system, appears to be supported. However, if one assumes that knowledge is power, then defendants with prior knowledge may be more powerful, and a favorable response to the more powerful is an argument consistent with the interactionist thesis. Unfortunately, it is this kind of equivocation in the interactionist thesis that makes it difficult to decide whether this finding is or isn't supportive.

Before proceeding, it should be noted that the relationship between a defendant's prior criminal record and the amount of charge reduction is not a simple linear relationship. As shown in Table 3, defendants with prior arrests and convictions do better than those with no prior arrests, but less well than those with arrests but no convictions. Perhaps the fact that defendants who successfully escaped the conviction label earlier, coupled with the knowledge they acquired in the course of being processed, explains why they are in a more favorable position than those with either no knowledge or those carrying forth a label that signifies a confirmed negative judgment by some earlier deviance processing agents.

Turning to an examination of the outcome for defendants whose cases were not disposed of at their first court presentation, we find the effect of defendants prosecuted for felony offenses to be the same as reported above, as is the finding for the effect of the prior criminal record. However, whereas the favorability of the charge reduction for defendants early disposed is affected by (1) the type of offense, (2) whether the defendant was charged with possession of a weapon, and (3) age, for defendants not early disposed these variables have no significant effects. Regrettably, no discernible pattern of differences between what affects this outcome for those early versus not early disposed is apparent. As such, we refrain from interpreting this difference between these two groups of defendants, but note its occurrence and stress the need for future research to probe this question in greater depth.

According to Table 3, the favorability of the charge reduction is also affected by whether a defendant was charged for resisting arrest, and the defendant's race/ethnicity. Defendants charged with resisting arrest are more likely to fare better, and defendants who are black are more likely to fare worse in the magnitude of their charge reduction. The fact that defen- 
Table 3. MAGNITUDE OF CHARGE REDUCTION RELATIVE TO POSSIBLE REDUCTION $\left(Y_{1}\right)$. REGRESSION COEFFICIENTS, STANDARD ERRORS (IN PARENTHESES) AND RELATED STATISTICS FOR STATISTICALLY SIGNIFICANT $(\rho<.05)$ VARIABLES

\begin{tabular}{|c|c|c|c|c|c|}
\hline & & \multicolumn{2}{|c|}{$\begin{array}{l}\text { Disposed of at First } \\
\text { Presentation }\end{array}$} & \multicolumn{2}{|c|}{$\begin{array}{c}\text { Not Disposed of at First } \\
\text { Presentation }\end{array}$} \\
\hline & & $\begin{array}{l}\text { Metric Co- } \\
\text { efficient and } \\
\text { Standard error }\end{array}$ & $\begin{array}{c}\text { Standardized } \\
\text { Coefficient }\end{array}$ & $\begin{array}{l}\text { Metric Co- } \\
\text { efficient and } \\
\text { Standard error }\end{array}$ & $\begin{array}{c}\text { Standardized } \\
\text { Coefficient }\end{array}$ \\
\hline$x_{1}$ & $\begin{array}{l}\text { Severity of first presen- } \\
\text { tation charge }\end{array}$ & n.s. & n.s. & n.s. & n.s. \\
\hline$x_{2}$ & $\begin{array}{l}\text { Most severe first pre- } \\
\text { sentation charge is } \\
\text { a felony }\end{array}$ & $\begin{array}{l}.13 \\
(.02)\end{array}$ & .34 & $\begin{array}{l}.08 \\
(.01)\end{array}$ & .21 \\
\hline \multirow[t]{4}{*}{$\dot{x}_{3}$} & Type of crime & & & & \\
\hline & Burglary & $\begin{array}{l}-.16 \\
(.05)\end{array}$ & -.40 & n.s. & n.s. \\
\hline & Assault & $\begin{array}{l}.20 \\
(.08)\end{array}$ & .56 & n.s. & n.s. \\
\hline & $\begin{array}{l}\text { Robbery } \\
\text { Larceny }\end{array}$ & n.s. & n.s. & n.s. & n.s. \\
\hline$x_{5}$ & Weapon charge & $\begin{array}{l}-.15 \\
(.05)\end{array}$ & -.16 & n.s. & n.s. \\
\hline $\begin{array}{l}x_{6} \\
x_{7}\end{array}$ & $\begin{array}{l}\text { Resist arrest charge } \\
\text { Race }\end{array}$ & n.s. & n.s. & $\begin{array}{l}.13 \\
(.02)\end{array}$ & .25 \\
\hline$x_{7}$ & $\begin{array}{l}\text { Spanish surname } \\
\text { Black } \\
\text { White }\end{array}$ & $\begin{array}{l}\text { n.s. } \\
\text { n.s. } \\
-\end{array}$ & $\begin{array}{l}\text { n.s. } \\
\text { n.s. } \\
-\end{array}$ & $\begin{array}{c}\text { n.s. } \\
-.04 \\
(.01)\end{array}$ & $\begin{array}{r}\text { n.s. } \\
-.10 \\
-\end{array}$ \\
\hline$x_{9}$ & Age & $\begin{array}{l}.006 \\
(.002)\end{array}$ & .16 & n.s. & n.s. \\
\hline \multirow[t]{4}{*}{$x_{11}$} & Criminal record & & & & \\
\hline & None & $\begin{array}{l}-.07 \\
(.03)\end{array}$ & -.14 & $\begin{array}{l}-.05 \\
(.01)\end{array}$ & -.13 \\
\hline & Arrest(s) only & $\begin{array}{l}.07 \\
(.03)\end{array}$ & .12 & $\begin{array}{l}.07 \\
(.02)\end{array}$ & .15 \\
\hline & Convictions & .00 & .02 & .02 & -.02 \\
\hline \multicolumn{2}{|c|}{$N$} & \multicolumn{2}{|c|}{448} & \multicolumn{2}{|c|}{944} \\
\hline \multicolumn{2}{|c|}{ Intercept } & \multicolumn{2}{|c|}{.09} & \multicolumn{2}{|c|}{.60} \\
\hline \multicolumn{2}{|l|}{$R^{2}$} & \multicolumn{2}{|c|}{.19} & \multicolumn{2}{|c|}{.13} \\
\hline
\end{tabular}

-Excluded category.

n.s. = not significant at .05 level. 
dants charged with resisting arrest do better on this outcome challenges the Chambliss and Seidman argument that defendants so charged are less favorably responded to in deference to the police. While we would not argue that deference to the police is unimportant, we would argue that court personnel are cognizant of "resisting arrest" often being a charge that is tacked onto weak cases. To the extent that this is true, defendants charged with resisting arrest may receive better charge reductions because the evidence against them for the most serious charge for which they were prosecuted (a charge other than the resisting arrest charge) is weak. By offering a better charge reduction, one reduces the likelihood that the defendant will refuse the plea offer and push for a trial, thereby raising court costs and increasing the possibility that the prosecutor will expend time and energy prosecuting a losing case. Thus, it may be that deference to police is a goal, but one of lower priority to the courts than the acquisition of speedy non-trial adjudicated convictions.

The finding that white defendants are more likely to receive better reductions than blacks is consistent with the interactionist thesis (Knowles and Prewitt; Quinney). However, as before, the combined effects of race, age, sex, and education are not strong enough to warrant a continued emphasis on power variables as being of prime importance in explaining the imperfect relation between acts and reactions. The effect at this stage of deviance processing is documented, but its relative size suggests greater attention be paid to other factors for explaining the imperfect correspondence between deviant acts and the reaction to same.

Finally, we identify those factors that did not have significant effects on $Y_{1}$, for they are nonetheless theoretically relevant. First, our measure of court workload suggests that better bargains are not offered on busier days. Perhaps the typificatory schemes described by Sudnow are so welldeveloped that changes in the daily workload have no effects. Indeed, we observed that regardless of the number of cases on the court calendar, the same limited amount of time was spent processing each case. Also, contrary to the argument we derived from Blumberg, and Rosett and Cressey, the number of court appearances does not independently affect the charge reduction outcome. Finally, as noted above, the sex and level of schooling of the defendant have no significant effects.

Turning to Table 4, we present the relationships between our independent variables and $Y_{2}$, the severity of the most serious charge for which the defendant is convicted, controlling for the severity of the most serious charge for which s/he was prosecuted. First, for defendants whose cases were disposed of at first presentation, we find the likelihood of being convicted of a more severe charge is increased if a defendant was prosecuted for possession of a weapon, and if this is the first time the defendant has been arrested. The likelihood of being convicted of a less severe charge is increased if the defendant was prosecuted for resisting arrest, if s/he is 
Table 4. SEVERITY OF DISPOSITION CHARGE $\left(Y_{2}\right)$. REGRESSION COEFFICIENTS, STANDARD ERRORS (IN PARENTHESES) AND RELATED STATISTICS FOR STATISTICALLY SIGNIFICANT $(\rho<.05)$ VARIABLES.

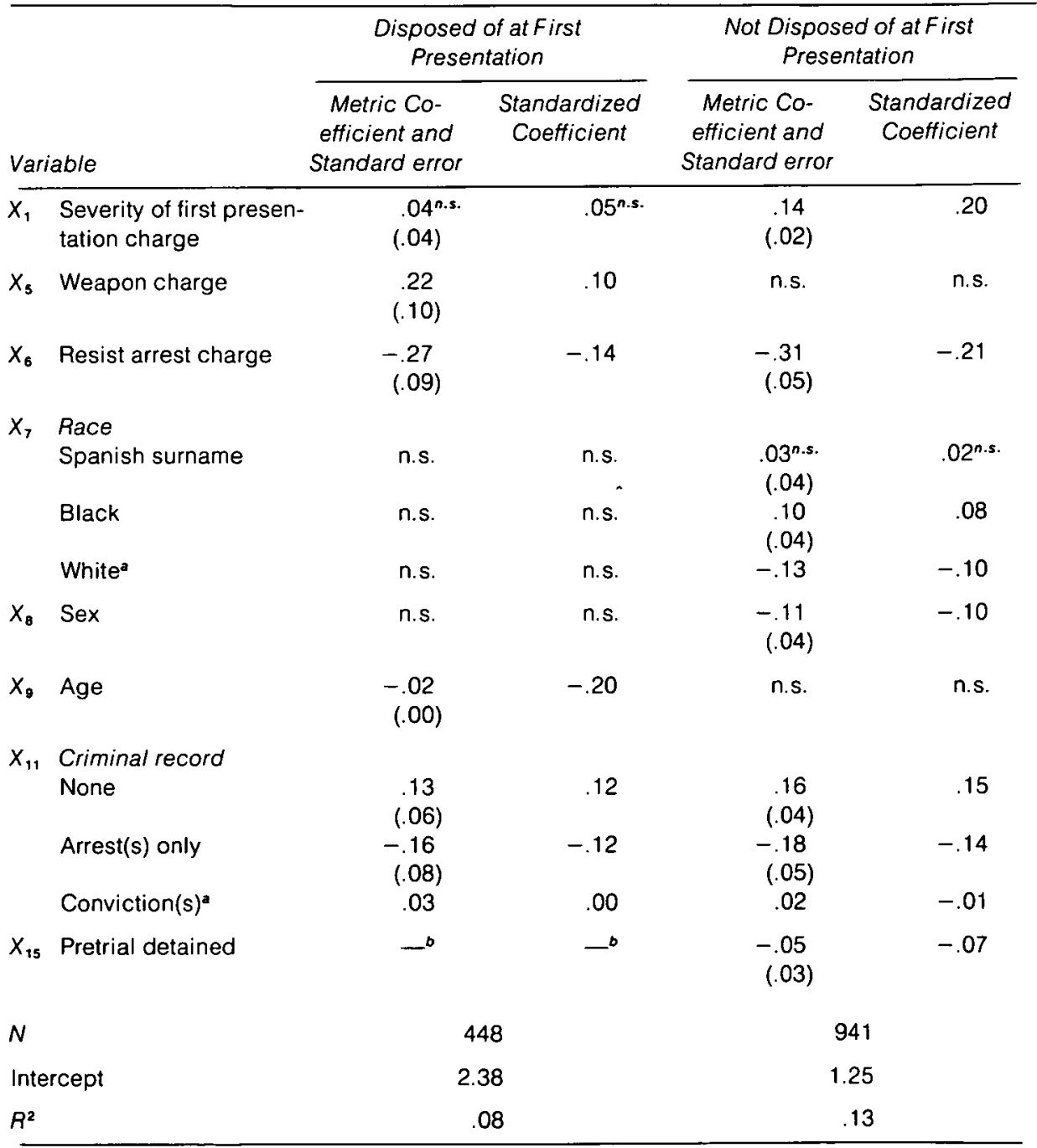

Excluded category.

DPretrial release status is inapplicable for defendants disposed of at first presentation.

n.s. $=$ not significant at .05 level. 
older, and if s/he has been arrested before but has no prior convictions for those arrests. Since the direction of these findings is identical to that noted for $Y_{1}$, we will not repeat our interpretative comments.

For defendants whose cases were not disposed of at their first court presentation, we find the likelihood of being convicted of a more severe charge is increased if the defendant is black or Spanish (blacks more so than Spanish), and if the defendant has never been arrested prior to this arrest. The likelihood of being convicted for a less severe charge is increased if the defendant was prosecuted for resisting arrest, if s/he is white, if the defendant is male, if the defendant has a prior arrest record with no convictions for those arrests, and if the defendant was detained in jail prior to his/her case disposition. Again, since the direction of these findings is identical to that noted for $Y_{1}$, we limit our discussion to the effects of those variables that were not previously interpreted.

Two factors that had no significant effects on $Y_{1}$ do affect the severity of the charge for which the defendant was convicted, independent of the severity of the charge for which s/he was prosecuted; i.e., the sex of the defendant, and the defendant's release status pending final disposition. Looking first at the effect of sex, we find that males fare better in this societal response decision. While the interactionist perspective does not address itself to sexual status as a relevant determinative factor, one can presume that like race and age, assumptions can be made about which status is the preferred status. If we assume that males are more powerful, then our finding that males fare better on this outcome can be construed as consonant with the interactionist thesis. Our court observations, however, lead us to offer an alternative explanation. In the case of criminal justice processing, females may be less favorably responded to not because of their powerlessness, but rather because expectations for them are higher. That is, unlike their male counterparts, females are presumed to be less likely to engage in law violating behavior. As such, when they are prosecuted for the kinds of serious non-female-type offenses here examined, they may be more severely responded to because they are violating expectations for appropriate sex-role behavior as well as appropriate law-abiding behavior. This explanation is consonant with Rasche's comment about traditional responses to female offenders, " . . very few women were labelled 'evil,' but when such labelling occurred, it was with a vengeance . . ." (15). Also, this is consistent with a dated but nonetheless interesting observation of Lombroso when he noted, when a woman did fall into the "born criminal" category, the assumption was she was even "more terrible than the equivalent male."

The finding that defendants who are detained pending their case disposition fare better, runs somewhat counter to the finding of prior research (Bernstein et al.; Landes, a; Roballo et al.). Perhaps the explanation lies in the fact that we have not differentiated between those defendants 
detained for short periods (e.g., those detained for a few days while they raise their bail money) versus those who remain in jail for longer periods until their case reaches final disposition. Future research should consider this. However, if our finding is replicated, two possible explanations come to mind. First, if a defendant had been detained for a considerable length of time (e.g., ninety days) the charge for which s/he is convicted may be greatly reduced so that it fits a lenient sentence, e.g., an unconditional discharge. The rationale behind the lenient sentence is credit towards time already served. Were the charge not greatly reduced, the lenient sanction would look strange since there is a presumption that sanctions are largely determined by the severity of the conviction charge. Our second speculative interpretation is that defendants who are in detention are sometimes there because they refused to plead guilty to a lesser charge at some earlier opportunity (e.g., at their first court presentation). To the extent that an organizational goal of the court is to do everything possible to avoid bringing a case to trial, a more favorable charge reduction offer to defendants who have been detained may reflect the court's willingness to up the bargain in the hopes that the defendant will accept a plea and waive his/her right to trial. Moreover, since the defendant has already served time, the court agents may feel less committed to a conviction on a more serious charge because the purpose of a serious conviction is to get a severe sanction. Clearly, a defendant who has served time in detention has already been severely sanctioned.

Before concluding, we note that two factors that did affect $Y_{1}$ have no significant effects on $Y_{2}$. These are, the type of offense, and whether the defendant was prosecuted for a felony. While we expected to find differences between those factors affecting $Y_{1}$ and those affecting $Y_{2}$, because $Y_{1}$ and $Y_{2}$ are different measures of the favorability of the charge reduction process, the findings don't manifest themselves in a way that suggest any immediate and compelling theoretical interpretation.

\section{Conclusions}

The purpose of our research was to explore the bases for variation in the response to deviants at one interim stage of deviance processing. The question guiding our effort was the degree to which interpretations of our findings were consistent with the interactionist perspective.

First, the interactionist emphasis on the imperfect correspondence between deviant acts and the response to those acts is, not unexpectedly, wholly warranted. Our research indicates that a variety of factors other than those defining the alleged deviant act affect the societal response. Second, the emphasis on the reactors, although not examined here directly (i.e., we did not assess the independent effects of having different prosecu- 
tors) does seem warranted, but with some caveats. When we do interpret certain findings as reflective of reactor held values towards the enforcement or non-enforcement of particular violations (e.g., assaults), and expectations for particular persons (e.g., females), these appear to be routinized values with some discernible basis, although not necessarily appropriately held. Our point is that the interactionist perspective leaves one to assume that variation attributable to the reactors is random, arbitrary, and almost always inappropriate. We contend that since our interpretations don't support such a blanket assertion, future research should probe deeper into reactor held values to determine what values are held, and when they become salient determinants of societal responses.

Third, we examined the effect of labels deviants carry forth from prior deviance processing stages (e.g., prior criminal record and release status pending case disposition). While we do find these variables have an effect, it is not in the direction predicted by the interactionist perspective. More importantly, our interpretation suggests that it is not the "prior deviance label" that is precipitating the effect. To illustrate, in the case of the criminal record, persons carrying forth a "prior arrestee" label do better than those with no prior criminal record at all. Our interpretation is that experience with the workings of the criminal justice system enhances one's negotiator abilities in the charge reduction process. While this is consonant with Schur's (a) discussion of the importance of negotiator ability, it cannot be said to affirm the accumulated disadvantaged status assertion so often thought of as central to the interactionist perspective. Ultimately, whether this finding is deemed supportive of the interactionist thesis or not seems to remain in the eyes of the interpreter.

Fourth, we examined a variety of defendant status variables to explore the degree to which socially disadvantaged statuses account for variation in the societal response. If one adopts the Tittle position, that the interesting interactionist assertion is that status considerations have a greater impact than factors defining the alleged deviant act, then the findings of our research contradict the interactionist thesis. We do not find that status considerations account for more of the variance than does the alleged deviant act. However, if one adopts the Becker (c) and Schur (c) assertion-regardless of the size of the effects relative to other variables, the interest is in determining whether status considerations have any independent effects - our research is supportive. Our own belief is that despite the protestations of the interactionists that they never meant to make social disadvantaged statuses the major determinant in their societal response model, that is the way it is generally read. Since other variables do explain more variance in the societal response, any further refinement of the perspective would do well to develop these other factors.

Finally, we examined some variables that reflected organizational constraints to explore how the goals of the deviance processing agency, in 
this case the courts, affected the societal response. While our conclusion must be tempered by our lack of direct measures of organizational variables, the majority of interpretations we put forth for our various findings fall well within this rubric. Specifically, our exploration of which factors affect differentiation in this societal response suggests that the bulk of factors having a significant impact can be interpreted in terms of organizational priorities. For example, the effects of (a) prosecuting defendants for felony defenses, (b) prosecuting defendants for resisting arrest, and (c) a defendant's release status pending case disposition, were all accounted for by reference to the court's need to process as many cases as possible within criminal court, to maximize the number of non-trial adjudicated convictions, and to minimize the court's expenditure of time and money. If such structural considerations play the major determinative role in societal response decisions, then the labelling perspective will have to include "bureaucratic impetus" as a major component.

In conclusion, the findings of our research are consonant with the thrust of the interactionist perspective, to the degree that one takes a broad view of what that perspective says. However, as stated in our introduction, the lack of specificity in the articulation of the perspective makes it difficult to refute. Thus, we deemed research aimed at stimulating refinement a necessary task. While the research we report on here does not specify a model of societal responses, it does suggest some direction for such a specification, as well as some shifts in the ordering of variables to account for variations in those responses.

\section{Notes}

1. Tittle argues that the provocative hypothesis is that social attributes of the defendant explain more variance than the alleged deviant act. Goode, Kitsuse, and Schur argue that the Tittle interpretation of the relevant hypothesis is not their interpretation, suggesting instead the hypothesis-social attributes explain some variance in societal responses. Obviously, the difference is on the importance of the size of the effect relative to the size of the effect of the deviant act. Since our research is exploratory, we examine the size of the effect of social attributes without regard to its size relative to effects of the deviant act. We will, however, allude to this discrepancy of interpretation in our discussion section.

2. Throughout this paper, when we referenced interactionist works, we include work that is sometimes categorized as representing the conflict rather than labelling approach. However, since much of the conflict perspective grows out of the labelling perspective, the work of conflict theorists is relevant to our research as well. While it is not within the scope of this paper to differentiate these two perspectives, to ignore one because we are concentrating on the other would not be justified.

\section{References}

Ares, C., A. Rankin, and H. Sturz. 1963. "The Manhattan Bail Project: An Interim Report on the Use of Pretrial Parole." New York University Law Review 38(January):67-92.

Becker, Howard S. a:1963. Outsiders: Studies in the Sociology of Deviance. New York: Free Press. 
b:1964. The Other Side: Perspectives on Deviance. New York: Free Press.

c:1973. "Labeling Theory Reconsidered." In Sheldon Messinger, et al. (eds.), Crime and Justice Annual. Chicago: Aldine.

Bensing, R., and O. Schroeder. 1960. Homicide in an Urban Community. Illinois: Thomas.

Bernstein, I., W. Kelly, and P. Doyle. 1977. "Societal Reaction to Deviants: The Case of Criminal Defendants." American Sociological Review (October):forthcoming.

Blumberg, A. S. 1967. "The Practice of Law as Confidence Game: Organizational Co-optation of a Profession." Law and Society Review 1(June):15-39.

Chambliss, W. J., and R. B. Seidman. 1971. Law, Order and Power. Reading: Addison-Wesley.

Cohen, J. 1968. "Multiple Regression as a General Data Analytic System." Psychological Bulletin 70(December):426-43.

Cressey, D. R. 1968. "Negotiated Justice." Criminologica 5(February):5-16.

Dawson, Robert O. 1969. Sentencing: The Decision as to Type, Length, and Conditions of Sentence. Boston: Little, Brown.

Emerson, Robert M. 1969. Judging Delinquency. Chicago: Aldine.

Erikson, K. T. 1964. "Notes on the Sociology of Deviance." In Howard S. Becker (ed.), The Other Side: Perspectives on Deviance. New York: Free Press.

Garfinkel, H. 1949. "Research Notes on Inter- and Intra-Racial Homicides." Social Forces 27(May):369-81.

Gibbs, J. a:1966. "Conceptions of Deviant Behavior: The Old and the New." Pacific Sociological Review 9(Spring):9-14.

b:1972. "Issues in Defining Deviant Behavior." In R. A. Scott and Jack Douglas (eds.), Theoretical Perspectives on Deviance. New York: Basic Books.

Goode, E. 1975. "On Behalf of Labeling Theory." Social Problems 22(June):570-83.

Gove, Walter. 1975. The Labeling of Deviance: Evaluating a Perspective. New York: Wiley.

Green, Edward. 1961. Judicial Attitudes in Sentencing. London: Macmillan.

Hagan, J. L. a:1974. "Extra-Legal Attributes and Criminal Sentencing: An Assessment of a Sociological Viewpoint." Law and Society Review 8(Spring):357-84.

b:1975. "Parameters of Criminal Prosecution: An Application of Path Analysis to a Problem of a Criminal Justice." Journal of Criminal Law and Criminology 65(December):536-44.

Hirschi, T. 1975. "Labeling Theory and Juvenile Delinquency: An Assessment of the Evidence." In Walter Gove (ed.), The Labelling of Deviance: Evaluating a Perspective. New York: Wiley.

Kerlinger, Fred, and Elazar Pedhazur. 1973. Multiple Regression in Behavioral Research. New York: Holt, Rinehart \& Winston.

Kitsuse, J., and A. Cicourel. 1963. "A Note on the Uses of Official Statistics." Social Problems 11(Fall):131-39.

Knowles, L., and K. Prewitt. 1972. "Racism in the Administration of Justice." In Charles Reasons and Jack Kuykendall (eds.), Race, Crime and Justice. Pacific Palisades: Goodyear.

Landes, W. M. a:1971. "An Economic Analysis of the Courts." The Journal of Law and Economics 14(April):61-107.

b:1974. "Legality and Reality: Some Evidence of Criminal Procedure." Journal of Legal Studies 4(June):287-337.

Lofland, John. 1969. Deviance and Identity. Englewood Cliffs: PrenticeHall.

Lombroso, Ceasar. 1893. The Female Offender. New York: Philosophical Library.

Miller, F. W. 1970. Prosecution: The Decision to Charge a Suspect with a Crime. Boston: Little, Brown. 
Nagel, Stuart. 1969. The Legal Process from a Behavioral Perspective. Homewood: Dorsey.

Newman, Donald. a:1956. "Pleading Guilty for Consideration: A Study of Bargain Justice." Journal of Criminology, Criminal Law, and Police Science 46(March-April): 780-90.

b:1966. Conviction: The Determination of Guilt or Innocence Without Trial. Boston: Little, Brown.

Pollner, M. 1974. "Sociological and Common-Sense Models of the Labeling Process." In Roy Turner (ed.), Ethnomethodology. Baltimore: Penguin.

Quinney, Richard. 1970. The Social Reality of Crime. Boston: Little, Brown.

Rasche, C. 1975. "The Female Offender as an Object of Criminological Research." In Annette Brodsky (ed.), The Female Offender. Beverly Hills: Sage.

Reasons, Charles. 1974. The Criminologist: Crime and the Criminal. Pacific Palisades: Goodyear.

Roballo, Johnny, James Hall, and Ronald Peck vs. Judges and Justices of New York City. 1974. Plaintiffs' Memorandum on the Merits. New York: United States District Court 74 Civ. 2113-MEL.

Rosett, Arthur, and Donald Cressey. 1976. Justice by Consent. Philadelphia: Lippincott.

Rubington, Earl, and Martin Weinberg. 1973. Deviance: the Interactionist Perspective. New York: Macmillan.

Schur, Edwin M. a:1971. Labeling Deviant Behavior. New York: Harper \& Row. b:1975. "Comment." In Walter Gove (ed.), The Labeling of Deviance. New York: Wiley.

Schwartz, R., and J. Skolnick. 1962. "Two Studies of Legal Stigma." Social Problems 10(April):133-42.

Scott, R. A. 1972. "A Proposed Framework for Analyzing Deviance as a Property of Social Order." In R. A. Scott and Jack Douglas (eds.), Theoretical Perspectives on Deviance. New York: Basic Books.

Sudnow, D. 1965. "Normal Crimes: Sociological Features of the Penal Code in a Public Defender Office." Social Problems 12(Winter):255-76.

Tittle, C. 1975. "Labelling and Crime: an Empirical Evaluation." In Walter Gove (ed.), The Labelling of Deviance. New York: J. Wiley.

Turk, Austin. 1969. Criminality and the Legal Order. Chicago: Rand McNally.

United States Department of Justice. 1975. Sourcebook of Criminal Justice Statistics1974. Washington: Government Printing Office.

Vetri, D. 1964. "Guilty Plea Bargaining: Compromises by Prosecutors to Secure Guilty Pleas." University of Pennsylvania Law Review 112(April):865-908.

Wald, P., and D. Freed. 1966. "The Bail Reform Act of 1966: A Practitioner's Primer." American Bar Association Joumal 52(October):940-45.

Wells, Edward, 1973. "Some Considerations in the Study of Plea Bargaining." Madison, Wisconsin, unpublished manuscript. 